\title{
SIKERJA, Tawaran bagi Pengembangan Ketenagakerjaan di Indonesia dalam Era VUCA ${ }^{1}$
}

\begin{abstract}
Achmad Zulfikar ${ }^{2}$
Indonesia dengan penduduk keempat terbesar di dunia memiliki angkatan kerja sekitar 118 juta lebih dengan angka pengangguran terbuka menurut data BPS 2015 mencapai sekitar 7 persen. Sementara dari sisi kualitas khususnya kompetensi, Indonesia menempati peringkat ke-50 menurut data World Economic Forum 2013. Bahkan jauh di bawah Malaysia yang menempati peringkat ke-20 atau Thailand yang berada di peringkat ke-30.[1]

Posisi Indonesia di tengah persaingan global dipengaruhi banyak faktor, salah satunya oleh VUCA. Istilah ini mulai diperkenalkan pada pertengahan tahun 1990-an oleh militer Amerika Serikat yang berusaha memetakan situasi global yang dihadapi. Pada akhirnya mereka berkesimpulan bahwa telah terjadi perubahan yang sangat signifikan di era milenial yang disebut dengan era VUCA (Volatility, Uncertainty, Complexity, Ambiguity). Istilah ini telah menjadi rujukan bagi institusi besar dunia dengan mengambil langkah konkrit untuk menyesuaikan diri. [2]
\end{abstract}

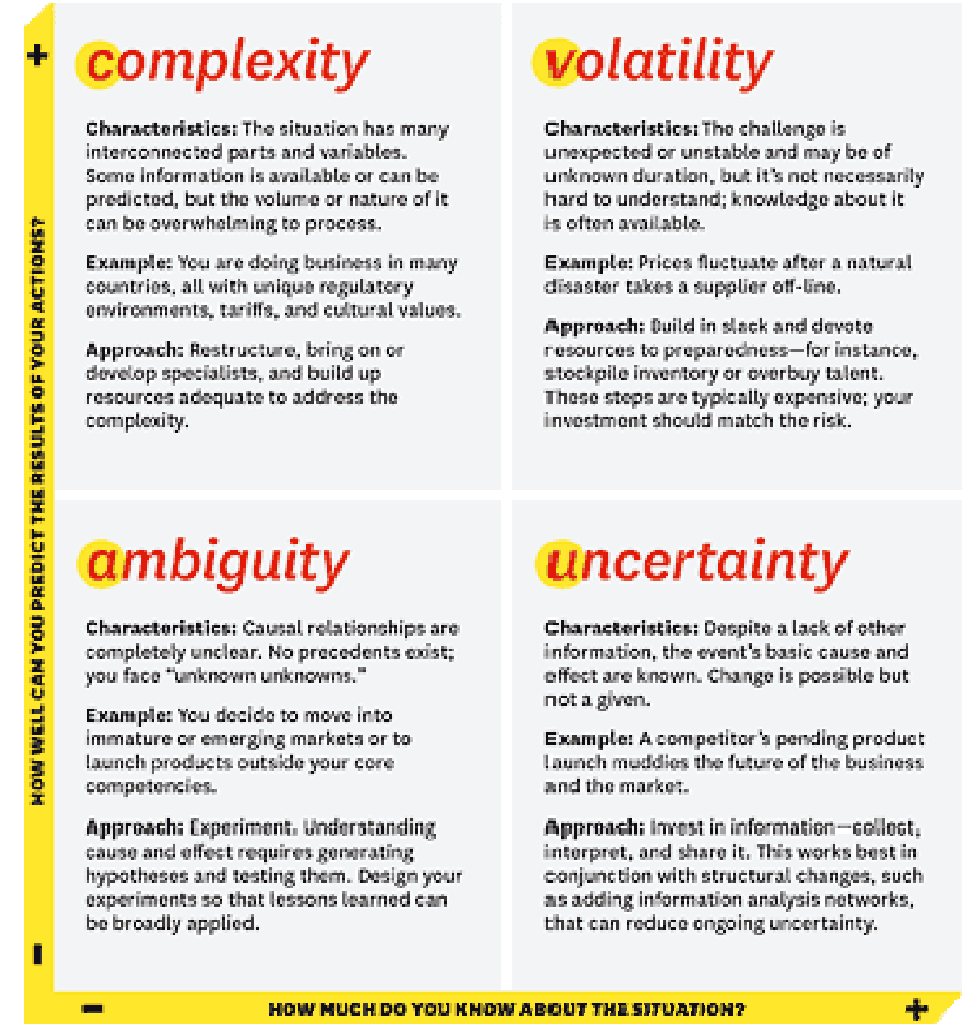

Sumber: Harvard Business Review

1 Esai yang diikutkan dalam Sayembara LPDP 2017 dengan judul: "SIKERJA, Sebuah Tawaran Solutif Pengembangan Ketenagakerjaan di Era VUCA"

2 Alumni Penerima Beasiswa Tesis dan Disertasi Lembaga Pengelola Dana Pendidikan (LPDP) Tahun 2016 dan Alumni Magister Ilmu Politik Universitas Hasanuddin. Email: apa@kabarfikar.com 
Sektor ketenagakerjaan merupakan salah satu bidang yang terkait dengan era VUCA. Perubahan yang cepat dan tidak terduga (volatility) menjadi tantangan dunia kerja. Ketidakmampuan tenaga kerja untuk mengikuti perubahan menyebabkan ia tidak dapat terserap dan menjadi pengangguran. Selanjutnya ketidakpastian (uncertainty) yang dialami oleh pemberi kerja menyebabkan terjadinya pemutusan hubungan kerja (PHK). Selain itu kompleksitas (complexity) yang terjadi di lapangan kerja, seringkali sulit dijelaskan dengan hitung-hitungan matematis. Terakhir, ambiguitas (ambiguity) terkait dengan regulasi yang mengatur bidang ketenagakerjaan di Indonesia yang belum mampu menjawab persoalan yang ada.

Berangkat dari analisa singkat terkait ketenagakerjaan di era VUCA, maka penulis menyarankan agar pemerintah mengembangkan SIKERJA (Sistem Informasi Ketenagakerjaan) yang merupakan sumbangsih ide solutif atas permasalahan bangsa. Penamaan sistem ini terinspirasi dari semangat Presiden Joko Widodo yakni Kerja... Kerja... Kerja... Di samping itu, pengembangan sistem yang melibatkan partisipasi publik diharapkan turut menyebarluaskan gerakan revolusi mental.

Sistem yang penulis tawarkan bukanlah sesuatu yang merombak birokrasi yang sudah ada, melainkan tawaran untuk menyederhanakan birokrasi sehingga dapat merespon kebutuhan masyarakat lebih responsif, efektif dan efisien. SIKERJA merupakan jembatan penghubung antara kepentingan tenaga kerja dengan lapangan kerja. Di satu sisi, sistem ini juga akan menerapkan revolusi mental kepada masyarakat melalui sistem yang transparan dan akuntabel. Selain itu, masyarakat diharapkan dapat responsif dan berdayasaing dalam pemanfaatan sistem ini nanti.

Pengembangan SIKERJA akan dilakukan melalui sistem komputerisasi yang memungkinkan pengguna dapat mengakses sistem ini secara daring (dalam jaringan). Sistem ini akan terhubung dengan basis data kependudukan yang telah terekan melalui KTP elektronik. Sehingga masyarakat yang telah memiliki KTP-el lebih mudah memanfaatkan sistem ini. Di samping itu, sistem yang telah diterapkan secara nasional melalui Kartu Kuning (Kartu Tanda Pencari Kerja) dapat menjadi basis data awal untuk pengembangan SIKERJA ini.

Ruang lingkup SIKERJA tidak hanya meliputi lapangan kerja di dalam negeri, tetapi juga dapat diperluas hingga lapangan kerja di luar negeri. Seperti di kawasan Asia Tenggara. [3] [4] Pemerintah dalam hal ini berfungsi sebagai fasilitator yang mengawasi operasional SIKERJA, sedangkan masyarakat (pencari kerja) dan pemberi kerja dapat berinteraksi sebagai pengguna. Kedepannya jika ide ini mendapat respon positif dari pemerintah, utamanya Kementerian Ketenagakerjaan Republik Indonesia, maka penulis sebagai Alumni LPDP siap untuk mengabdi dan menjadi bagian dari solusi. Indonesia, kami pasti mengabdi.

\section{References}

[1] World Economic Forum. The Global Competitiveness Report 2013-2014. Retrieved from: https://www.weforum.org/reports/global-competitiveness-report-2013-2014

[2] Harvard Business Review. What VUCA Really Means for You. Retrieved from: https://hbr.org/2014/01/what-vuca-really-means-for-you

[3] Zulfikar, Achmad. (2015). Mapping the Position of Indonesian Migrant Workers towards ASEAN Economic Community 2015. Retrieved from: http://osf.io/5cefw

[4] Zulfikar, Achmad. (2016). Peluang dan Tantangan Pekerja Migran Indonesia dalam Masyarakat Ekonomi ASEAN. Retrieved from: http://osf.io/preprints/inarxiv/9twcv 